УДК 662.73

DOI https://doi.org/10.32838/2663-5941/2020.4/20

Гулей О.Б.

Українська інженерно-педагогічна академія

\title{
ВИБІР ОПТИМАЛЬНОГО ВУГІЛЛЯ УКРАЇНСЬКОГО ВИДОБУТКУ ДЛЯ ПАРОКИСНЕВОЇ ГАЗИФІКАЦЇ̈ В СТАЦІОНАРНОМУ ШАРІ
}

Метою роботи є дослідження можливості вибору оптимальної марки вугілля українського видобутку для ефективної внутрішньочиклової газифікаиії його у бінарному термодинамічному ичиклі на ТЕС.

На підставі результатів літературного огляду з теми дослідження показано, щз в дослідженнях технологій газифікачії вугілля для отримання газового енергетичного палива вплив складу вихідного вугілля, як правило, не був предметом спеціального розгляду. Тому зроблено висновок, що натепер відсутній універсальний, заснований на системному підході метод попереднього вибору енергетичного вугілля для наперед заданої технологї газифікащії.

Предметом дослідження є вплив складу вихідного вугілля на склад генераторного газу і його основні теплотехнічні характеристики, що дає підставу для подальшого вибору оптимального за складом вугілля.

Як критерій оптимальності вибору запропоновано використовувати величину хімічного коефіцієнта корисної дії (ККД) процесу газифікаиї̈, а також сумарну чутливість изього ККД до зміни вмісту компонентів складу вугілля залежно від неоднорідності иього складу.

Як інструмент дослідження автором використано метод оиінки складу генераторного газу алгебраїчний метод Дешаліта. Метод дає змогу розрахунковим шляхом отримувати кількісні оцінки складу продуктів газифікаиіі залежно від характеристик складу вихідного вугілля, складу дуття, температури та тиску в газогенераторі. Допущення в методі Дешаліта, як показав досвід, не призводять до суттєвих помилок отриманих очінок.

На прикладі поширених марок енергетичного вугілля математичним моделюванням прочесу газифікаиії (технологія «Лургі») отримані характеристики газового палива, на підставі яких можна зробити вибір оптимальної марки вихідного вугілля.

Ключові слова: вугілля, генераторний газ, газогенератор, дуття, шар, хімічний ККД, питома теплота згорання, температура, тиск, вихід газу, склад, зольність, вологість.

Постановка проблеми. Природний газ має великі технологічні переваги перед іншими видами палива на теплових електричних станціях (TEC). Це практично єдиний вид палива, придатний для безпосереднього використання в газотурбінних енергетичних установках (ГТУ) блоків парогазових установок (ПГУ) на ТЕС.

Тому актуальною стає проблема заміни імпортованого природного газу штучним газовим паливом. Таким паливом $є$ горючі газові суміші, що одержані в результаті газифікації вугілля $[1$, с. 5 , $27,163 ; 2$, с. 5,21$]$.

Апарати, призначені для газифікації, називають газогенераторами, гази, що виробляються в них - генераторними газами.

Сировиною для газифікації може служити вугілля з великим діапазоном відмінності характеристик, у тому числі і низькоякісне. Зазначимо, що в українських родовищах велика частка запасів припадає на вугілля з високим вмістом золи, сірки, важких металів, а крім того, в країні накопичено великі обсяги відходів вуглевидобутку та збагачення вугілля [1, с. 159$]$.
Аналіз останніх досліджень i публлікацій. $€$ багато технологій газифікації вугілля $[1 ; 2 ; 4]$, але нині більшість їх не виходить за межі дослідних зразків, тому розглянемо такі, що найбільш поширені на практиці і мають тривалу історію застосування.

Так, у промисловому масштабі широко освоєно технологію «Лургі» - газифікацію кускового палива в стаціонарному шарі під тиском від 2,0 МПа до 3,0 МПа і температурі процесу до $1200^{\circ} \mathrm{C}$ на парокисневому або пароповітряному дутті [4, с. 395]. Зазначимо, що зараз у світі в експлуатації більше 140 генераторів за схемою «Лургі».

Газифікація в киплячому розрідженому шарі - технологія «Вінклера» (нині в світі працює до 50 газифікаторів) - за часом застосування одна 3 найстаріших. Паливо дрібнозернисте (розмір частинок менше 10 мм). Процес йде за атмосферного тиску і температури до $1100{ }^{\circ} \mathrm{C}$ [4, с. 396].

Технологія за методом "Shell" - газифікація в потоці пилоподібного вугілля сухим шляхом. Шлаковидалення в рідкому вигляді. Тиск - 3,1 МПа. Температура потоку від $1400^{\circ} \mathrm{C}$ до $1500{ }^{\circ} \mathrm{C}$ [1, с. 141$]$. 
Технологія газифікації вугілля може бути економічно ефективною у разі використання дешевого вугілля і застосування комплексних газохімічних схем процесу, а також у разі наближення виробництва до місць видобутку вугілля [1, с. 149; 3, с. 139]. Для України необхідні вугільні енерготехнології, які дадуть змогу використовувати високозольне $\left(\mathrm{A}^{\mathrm{p}}>35 \%\right)$ низькореакційне вугілля, а також відходи вуглевидобутку і вуглезбагачення $3 \mathrm{~A}^{\mathrm{p}}$ від $35 \%$ до 65\% і високим вмістом сірки $[1$, с. $165 ; 2 ; 6]$. Тут газифікація виступає процесом збагачення високобаластного вугілля.

Підвищити технологічні показники генерації на ТЕС можна у разі використання бінарного термодинамічного циклу в ПГУ з внутрішньоцикловою газифікацією вугілля $[1$, с. $167 ; 6]$. Спалювання газу відбувається в камері згоряння ГТУ і забезпечує більш високі температури робочого тіла порівняно $з$ паровим циклом. У ПГУ ККД (нетто) досягає до 48\%. До речі, ТЕС на базі ПГУ відповідають жорстоким екологічним вимогам.

На ефективність процесу газифікації суттєво впливають хімічні і фізичні властивості палива [2, с. $82 ; 5$, с. 35]. Характер цього впливу в загальному випадку досить суперечливий, важко піддається систематизації. Так, для газифікації вугілля 3 рідким шлаковидаленням низька температура плавлення золи $є$ позитивним фактором. А у разі газифікації в шарових газогенераторах 3 мокрим золовидаленням бажано отримати тугоплавку золу.

У разі газифікації низькореакційного вугілля в газогенераторі температура повинна бути не менше $1000{ }^{\circ} \mathrm{C}$, що необхідно для потрібної продуктивності процесу. А для високосірчаного вугілля переважні методи газифікації, які обмежують температури в газогенераторі рівнем, що забезпечує ефективне зв' язування сірки з допомогою присадок доломіту і вапняку.

Таким чином, можна стверджувати, що вимоги до вибору вугілля значною мірою визначаються способом газифікації.

Для довідки доцільно звернутися до ГОСТ 25543-88 [8] (скасований з 01.01.2019), де наведено класифікацію вугілля, яке придатне для виробництва змішаного генераторного газу на газогенераторах стаціонарного типу. Це вугілля таких марок, груп і підгруп: Б, ЗБВ, ЗБФ; ДГ, ДГФ; КС, 1КС, 2КС, 1КСВ, 1КСФ, 2КСВ, 2КСФ; ГЖО, 1ГЖО, 1ГЖОФ; СС, 2СС, ЗСС; ПЗ, ПСВ; П, 1Т, 1ТВ. Як видно з переліку, для газифікації придатне широке коло марок вугілля, що суттєво розрізняються за характеристиками.
Таким чином, для вибору оптимальної марки вугілля замовник, виходячи на ринок і знаючи характеристики заданої технології газифікації, повинен проаналізувати дані про вугілля багатьох марок і порівняти характеристики одержуваних 3 них газів, насамперед їх калорійність.

Відзначимо, що в рамках літературного пошуку за доступними джерелами нам не вдалося знайти спеціалізованої методики, налаштованої до виконання такого аналізу. Тому доцільно виділити низку публікацій, в яких придатність українського вугілля до газифікації розглядається більш системно, що важливо для подальшого аналізу.

Так, у роботі [9, с. 11] стверджується, що методам газифікації підвладне все вугілля, починаючи від бурого і до антрациту. Наведені практичні результати газифікації вугілля марок ГЖ і бурого вугілля. Також згідно з [6] уже відпрацьовані на практиці технології газифікації вугілля, включаючи “Shell” [11], які підходять для всіх типів вугілля.

У роботі [10], говорячи про плани будівництва в Україні заводів з газифікації вугілля за технологією "Shell", один 3 провідних науковців галузі висловлюється про те, що: «Мінеральна частина вугілля вітчизняного видобутку містить майже $23 \%$ окису заліза і лужноземельних елементів, тоді як австралійська і американська - лише від 3\% до 5\%; щодо сірки це відношення становить $3,5 \%$ порівняно з $0,5 \%$ ». Тобто саме посередні характеристики українського вугілля $є$ самостійною складною проблемою.

3 іншого боку, достовірні запаси ЛьвівськоВолинського бурого вугілля - до 2 млрд. т. Після збагачення його можна було б ефективно газифікувати [12].

3 результатів огляду за темою дослідження можна зробити висновок, що нині в Україні немає методики попереднього вибору оптимального вихідного вугілля для газифікації на ТЕС. Тому залишається актуальним питання вибору вугілля за умови, що технологія газифікації вже задана.

Постановка завдання. Метою статті $є$ розробка методу вибору марки оптимального вугілля для газифікації. Метод базовано на математичній моделі газифікації вугілля за заданою технологією в газогенераторі.

Математичне моделювання процесу виконується на основі апріорної інформації про склад робочої маси вихідного вугілля і режимні характеристики газогенератора. Характеристики шуканого вугілля повинні задовольняти запропонованому в роботі критерію оптимальності хімічному ККД процесу газифікації та чутливості його до змін вмісту вихідного палива. 
Виклад основного матеріалу дослідження. У роботі розглянуто варіант парокисневої газифікації в стаціонарному шарі вугілля під тиском, яка дає змогу застосовувати більшість марок вугілля й отримувати хімічні продукти 3 мінімальною кількістю стадій переробки Такий процес на практиці масово реалізований у технології «Лургі» $[1$, c. $1 ; 3$, c. $126 ; 4$, c. $395 ; 5$, c. 19 , c. $29 ; 6 ; 14$, c. 45].

У процесі газифікації більшість органічної маси палива перетворюється на газ і також утворюються смолопродукти і бензин [3, с. 121; 5 , c. $119 ; 14]$.

Реакції взаємодії водяної пари 3 вуглецем і сумарні процеси газифікації $\epsilon$ ендотермічними. Джерелом тепла служить екзотермічна реакція часткового окислення вугілля, для чого в газогенератор подають парокисневу суміш.

Для розрахунку складу продуктів газифікації нами застосовано метод алгебри Дешалита, який базується як на положеннях хімічної кінетики, так i на результатах промислових випробувань газифікаторів [3, с. $133 ; 15$, с. 14$]$.

Під час газифікації на парокисневому дутті під тиском мають місце реакції, що визначають склад газу, що виходить [13, с.133; 14; 15, с. 122]:

$$
\begin{aligned}
\mathrm{C}+\mathrm{CO}_{2} & \rightleftarrows 2 \mathrm{CO}-\mathrm{Q}_{1} ; \\
\mathrm{CO}+\mathrm{H}_{2} \mathrm{O} & \rightleftarrows \mathrm{CO}_{2}+\mathrm{H}_{2}+\mathrm{Q}_{2} ; \\
\mathrm{C}+2 \mathrm{H}_{2} & \rightleftarrows \mathrm{CH}_{4}+\mathrm{Q}_{3},
\end{aligned}
$$

де $\mathrm{Q}_{\mathrm{i}}$ - тепловий ефект відповідної реакції.

Тут передбачається, що горюча частина палива під час газифікації складається тільки з вуглецю С. Відзначимо, що на практиці вміст основних компонентів газу близький до розрахункових значень [3, с. $136 ; 15$, с. 124].

За даними практичних досліджень [15, с. 122] приймаємо, що склад генераторного газу містить такі компоненти: $\mathrm{CO}, \mathrm{CO}_{2}, \mathrm{H}_{2}, \mathrm{CH}_{4}, \mathrm{H}_{2} \mathrm{O}$.

Замінюємо шуканий процентний вміст компонентів парціальними їх тисками. Тоді сума парціального тиску компонентів дорівнює загальному тиску газу, що утворився (цей тиск задає дуття):

$$
P_{\text {заг }}=P_{C O}+P_{\mathrm{CO}_{2}}+P_{\mathrm{H}_{2}}+P_{\mathrm{CH}_{4}}+P_{\mathrm{H}_{2} \mathrm{O}} .
$$

Константи рівноваги реакцій (1-3) розраховують за рівняннями:

$$
\begin{gathered}
\frac{P_{\mathrm{CO}}^{2}}{P_{\mathrm{CO}_{2}}}=K_{1}, \\
\frac{P_{\mathrm{CO}_{2}} P_{\mathrm{H}_{2}}}{P_{\mathrm{CO}} P_{\mathrm{H}_{2 O}}}=K_{2},
\end{gathered}
$$

$$
\frac{P_{C H_{4}}}{P_{H_{2}}}=K_{3} .
$$

Для оцінки констант рівноваги реакцій $K_{j}$ (5-7) Дешалітом зроблено припущення, що довідкові значення $K_{j}$, отримані за умови рівноваги цих реакцій, можна використовувати і в разі розрахунку газифікації. Згідно $3[15$, с. 17$]$ це не призводить до суттєвих помилок.

Рівняння (8) складене, виходячи з того, що відношення вмісту водню до кисню в одержаному газі і в початковій газифікованій суміші не змінюється $[3$, с. $135 ; 15$, с. 123$]$ :

$$
\frac{P_{\mathrm{H}_{2} \mathrm{O}}}{2 P_{\mathrm{O}_{2}}+P_{\mathrm{H}_{2} \mathrm{O}}}=D
$$

Введемо такі позначення:

$$
P_{\mathrm{H}_{2}}=x ; P_{\mathrm{CH}_{4}}=t ; P_{\mathrm{H}_{2} \mathrm{O}}=y ; \quad K_{1}=B ; \quad P_{\mathrm{CO}_{2}}=u ;
$$
$K_{2}=A ; K_{3}=C ; P_{C O}=z$;

На підставі цих позначень рівняння (5-8) приймуть такий вигляд:

$$
\begin{gathered}
x+z+t+u+y=\mathrm{P}_{\text {заг }} \\
\frac{z^{2}}{u}=B ; \frac{u x}{z y}=A ; \frac{t}{x^{2}}=C ; \quad \frac{2 t+y+x}{2 u+y+z}=D .
\end{gathered}
$$

Після перетворень цих рівнянь одержимо два алгебраїчні рівняння:

$$
\begin{gathered}
x+\frac{x z}{A B}+z+\frac{z^{2}}{B}+C x^{2}-P_{\text {зах }}=0 \\
x+z x\left(\frac{1-D}{A B}\right)-z D-\frac{2 D}{B} z^{2}+2 C x^{2}=0,
\end{gathered}
$$

де величина $D \epsilon$ відношенням водню до кисню в дутті [3, с. 135].

Значення констант рівноваги залежно від температури для реакцій (1-3) наведені в [16, с. 162]. Вирішення одержаної системи рівнянь (9-10) одержують стандартним чисельним методом на ПЕОМ.

За розрахованими парціальними тисками компонентів газової суміші визначаємо їх відповідні вмісти. Оскільки генераторний газ на виході осушують, то $P_{\mathrm{H}_{2} \mathrm{O}}=0 \%$. Одержаний газ є сумішшю газів та пари у вигляді смолопродуктів і бензинів, які конденсуються за температури вище нуля $[3$, с. 136; 15, с. 126]. Їх вихід, а також втрати вуглецю з унесенням і провалом визначають з урахуванням даних експериментів [3, с. 127].

Питомий вихід (на 1 кг твердого палива) сухого газу $V_{c 2}$, нм $^{3} /$ кг розраховують за балансом вуглецю [3, с. $136 ; 15$, с. 126]. 
Величина хімічного ККД є однією з вирішальних енергетичних характеристик процесу газифікації. Цей ККД характеризує ефективність перетворення теплоти вихідного вугілля в хімічно потенційне тепло генераторного газу. Ця ефективність визначається саме складом вугілля (вибору вугілля), на відміну від термічного ККД процесу, який залежить і від умов теплообміну топки 3 навколишнім середовищем [15, с. 73$]$.

Хімічний ККД не залежить від того, які енергетичні втрати мають місце в такому газифікаторі у разі забезпечення заданих величин температури і тиску або втрати дуття у разі окислення шару палива. Кінетика хімічних реакцій не залежить від технологій забезпечення необхідних умов, але залежить від складу вихідного вугілля. Відзначимо, що в умовах заданого процесу газифікації вплив усіх витрат вуглецю на ці ККД порівняно.

Тому під час вибору вихідного вугілля як критерій ми використовуємо величину хімічного ККД, \%, цього процесу, яку визначають за формулою [3, с. 138]:

$$
\eta_{\text {xin }}=\frac{Q_{c .2 .}^{d} V_{c .2 .}}{Q_{u}^{p}} 100
$$

де $V_{c .2 .}$ - вихід сухого газу, нм ${ }^{3} /$ кг,$Q_{c .2 .}^{d}-$ нижча теплота згорання сухого газу, кДж/м ${ }^{3}, Q_{u}^{p}-$ нижча теплота згорання вихідного вугілля, кДж/кг.

Довідкові дані щодо $Q_{u}^{p}$ проєктного вугілля наведені в [17, с. 129].

Своєю чергою нижчу теплоту згорання $Q_{c .2}^{d}$ газового палива, кДж/м ${ }^{3}$ (сухого газу), визначають за законом адитивності за виразом:

$$
Q_{c .2 .}^{d}=\sum_{j}\left(C_{j} / 100\right) Q_{j}
$$

де $C_{j}$ - молярна концентрація $j$-го горючого компонента в газовому паливі, \%; $Q_{j}$ - нижча теплота згорання $j$-го горючого компонента, кДж/ $\mathrm{m}^{3}$.

Нижчу теплоту згорання компонентів палива наведено в [17, с. 15].
За зміни складу вихідного вугілля нижчу теплоту згорання $Q_{\mathrm{H}}^{\mathrm{p}}$ розраховують за формулою Д.І. Менделєєва:

$$
\begin{gathered}
Q_{\mathrm{H}}^{\mathrm{p}}=339.1 \mathrm{C}^{\mathrm{p}}+ \\
+1055,6 \mathrm{H}^{\mathrm{p}}+108,9\left(S_{\text {гор }}^{\mathrm{p}}-\mathrm{O}^{\mathrm{p}}\right) 24,42 W^{\mathrm{p}}, \text { кДж/кГ }(13)
\end{gathered}
$$

де $C^{p}, H^{p}, O^{p}, S_{\text {гор }}^{p}, W^{p}$ - компоненти робочої маси вугілля.

Основні характеристики для моделювання газифікації в нашому дослідженні такі: температура процесу $-900{ }^{\circ} \mathrm{C}$; тиск процесу (дуття) - 3,46 МПа; дуття з відношенням тиску водяної пари до кисню - 85:15.

Результати розрахунків вмісту та нижчої теплоти згорання компонентів і теплоти згорання отриманого генераторного газу наведені в таблиці 1.

У таблиці 2 наведені розрахункові характеристики марок енергетичного вугілля українського видобутку для дослідження [17, с. 129].

Вихід сухого газу, теплота згорання і хімічний ККД газифікації для палива, отриманого з відповідного вихідного вугілля, наведені в таблиці 3.

За даними розрахунків, наведених у таблиці 3 , можна зробити попередній вибір вугілля для заданої технології. Так, максимальний хімічний ККД $67,43 \%$ має вугілля марки ПА Вуглегірського Східного родовища Донецького басейну. Мінімальний хімічний ККД 53,96\% має вугілля марки Ж, ОС, промпродукт Донецького басейну.

Але навіть для попередньої оцінки вибору вугілля даних про величину хімічного ККД газифікації не досить, значною мірою це пов'язано з особливістю вугілля - винятковою неоднорідністю складу і властивостей, незалежно від того, чи надійшло вугілля безпосередньо $з$ пласта або це товарна проба. Також неоднорідність вугілля залежить від родовища [3, с. 217] і від багатьох природних і техногенних факторів [18, с. 20], надійний контроль яких на етапі поставок вугілля практично неможливий.

Тому, на наш погляд, на етапі вибору вугілля необхідно аналізувати вплив на хімічний ККД газифікації зміни вмісту компонентів вихідного вугілля. Для

\begin{tabular}{|c|c|c|c|c|c|c|}
\hline Компоненти газу & $\mathrm{CO}_{2}$ & $C O$ & $\mathrm{CH}_{4}$ & $\mathrm{H}_{2}$ & $\mathrm{H}_{2} \mathrm{O}$ & Всього \\
\hline Парціальний тиск Р, МПа & 0,434 & 1,295 & 0,216 & 1,045 & 0,464 & 3,455 \\
\hline Вміст газу (вологий), \% & 12,57 & 37,49 & 6,26 & 30,25 & 13,43 & 100 \\
\hline Вміст газу (сухий), \% & 14,52 & 43,30 & 7,23 & 34,95 & 0,00 & 100 \\
\hline $\begin{array}{l}\text { Нижча теплота згорання } \\
\text { компонентів газу, МДж/м }\end{array}$ & - & 12.64 & 35.82 & 10.80 & - & - \\
\hline $\begin{array}{l}\text { Складник до теплоти згорання } \\
\text { компонентів газу, МДж/м }{ }^{3}\end{array}$ & - & 5,473 & 2,59 & 3,775 & - & 11,838 \\
\hline
\end{tabular}

Вміст і теплові характеристики компонентів генераторного газу, отриманого в процесі

Таблиця 1 моделювання газифікації 
Таблиця 2

Розрахункові характеристики варіантів вугілля

\begin{tabular}{|c|c|c|c|c|c|c|}
\hline $\begin{array}{c}\text { № вугілля } \\
\text { в роботі / } \\
\text { (за нормативом) } \\
\text { Басейн } \\
\end{array}$ & $\begin{array}{c}1 /(9) \\
\text { Донецький }\end{array}$ & $\begin{array}{c}2 /(11) \\
\text { Донецький }\end{array}$ & $\begin{array}{c}\text { 3/ (13) } \\
\text { Донецький }\end{array}$ & $\begin{array}{c}\text { 4/ (24) } \\
\text { Донецький }\end{array}$ & $\begin{array}{c}5 /(66) \\
\text { Львівський }\end{array}$ & $\begin{array}{c}\text { 6/ (65) } \\
\text { Дніпровський }\end{array}$ \\
\hline $\begin{array}{ll}\text { Марка, } \\
\text { вугілля }\end{array}$ & Ж, Р & $\begin{array}{c}\text { Ж, ОС, пром- } \\
\text { прод. }\end{array}$ & П, Р & П, А & Г, Р, відсів & $15, P$ \\
\hline $\mathrm{W}^{\mathrm{p}, \%}$ & 6,0 & 12,0 & 6,0 & 5,0 & 10,0 & 18.0. \\
\hline $\mathrm{A}^{\mathrm{p}, \%}$ & 30,1 & 37,0 & 32,0 & 24,7 & 27,0 & 17.9 \\
\hline$S_{\text {сумарна }}^{\mathrm{p}} \%$ & 2,5 & 2,6 & 2,2 & 2,4 & 2,8 & 3,6 \\
\hline $\mathrm{C}^{\mathrm{p}}, \%$ & 53,4 & 41,1 & 55,2 & 62,7 & 49,9 & 42.6 \\
\hline $\mathrm{H}^{\mathrm{p}}, \%$ & 3,3 & 2,7 & 2,5 & 3,7 & 3,3 & 3.7 \\
\hline $\mathrm{N}^{\mathrm{p}}, \%$ & 1,0 & 0,8 & 1,0 & 1,1 & 0,9 & 0.5 \\
\hline $\mathrm{O}^{\mathrm{p}}, \%$ & 3,7 & 3,8 & 1,1 & 1,4 & 6,2 & 13.7 \\
\hline $\mathrm{Q}_{\text {н вуг. }}^{\mathrm{p}}, \kappa Д ж /$ кг & 21314 & 16364 & 21331 & 25154 & 19790 & 16812 \\
\hline
\end{tabular}

Вихід сухого газу, теплота згорання і хімічний ККД газифікації

Таблиця 3 для вугілля розрахункової характеристики

\begin{tabular}{|l|c|c|c|c|c|c|}
\hline \multicolumn{1}{|c|}{ № вугілля в роботі /норматив } & $1 /(9)$ & $2 /(11)$ & $3 /(13)$ & $4 /(24)$ & $5 /(66)$ & $6 /(65)$ \\
\hline Вихід сухого газу $V_{c 2}, \mathrm{Hм}^{3} /$ кг & 1,136 & 0,746 & 1,173 & 1,433 & 1,06 & 0,92 \\
\hline Теплота згорання газу, МДж/м ${ }^{3}$ & 11,838 & 11,838 & 11,838 & 11,838 & 11,838 & 11,838 \\
\hline Нижча теплота згорання вугілля $\mathrm{Q}_{\text {н вуг. }}^{\text {p }}$, КДж / кг & 21314 & 16364 & 21331 & 25154 & 19790 & 16812 \\
\hline Хімічний ККД, $\eta_{\text {хім }}, \%$ & 63,1 & 53,96 & 65,11 & 67,43 & 63,43 & 64,82 \\
\hline
\end{tabular}

цього необхідно отримати кількісну оцінку зміни виходу моделі газифікації (хімічного ККД) у разі відхилення параметрів моделі (вмісту компонентів вихідного вугілля) від їх номінальних значень.

Сама зміна виходу математичної моделі у разі відхилення іï параметрів характеризує чутливість моделі. А аналіз чутливості зводиться до оцінки хімічного ККД газифікації за умовою зміни вмісту компонентів вугілля.

Метод такого аналізу - імітаційне моделювання. За методом, змінюючи значення вмісту одного 3 компонентів 3 деяким кроком у разі постійних значень інших і щоразу перераховуючи результат (хімічний ККД), отримують функцію залежності чутливості ККД від вмісту компонентів палива. Перша похідна цієї функції по параметру - чутливість, кількісна оцінка якої називається коефіцієнтом чутливості моделі по параметру:

$$
S_{j}=\frac{d y}{d x_{j}} \approx \frac{\Delta y}{\Delta x_{j}} .
$$

де $S_{j}$ - коефіцієнт чутливості моделі у по параметру $x_{j}$.

На рис. 1-3 показані результати розрахунку чутливості хімічного ККД до зміни компонентів вихідного вугілля.

У таблиці 4 представлені результати розрахунку наведених функцій чутливостей хімічного
ККД газифікації до вмісту компонентів вихідного вугілля (вугілля в табл. 2). Тут величина $\Delta x_{j}$ приймається рівною $0,01 x_{j}$ у формулах (14) для всіх варіантів палива, а величина $x_{j}$ приймається для кожної $j$ відповідно до вмісту вугілля з табл. 2 .

Розрахунок наведених чутливостей виконують за формулою (15):

$$
S_{j}^{\text {нав }}=\left(\frac{\Delta \eta}{\Delta x_{j}}\right) / C,
$$

де $\mathrm{C}$ - розрахунковий вміст вуглецю у вихідному паливі, \%.

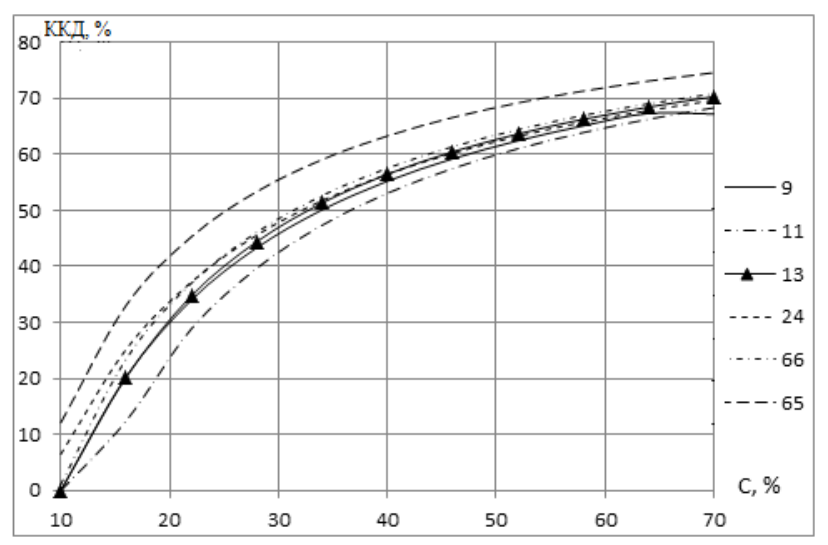

Рис. 1. Функції чутливості хімічного ККД вуглефікації до зміни вмісту вуглецю вихідного вугілля 


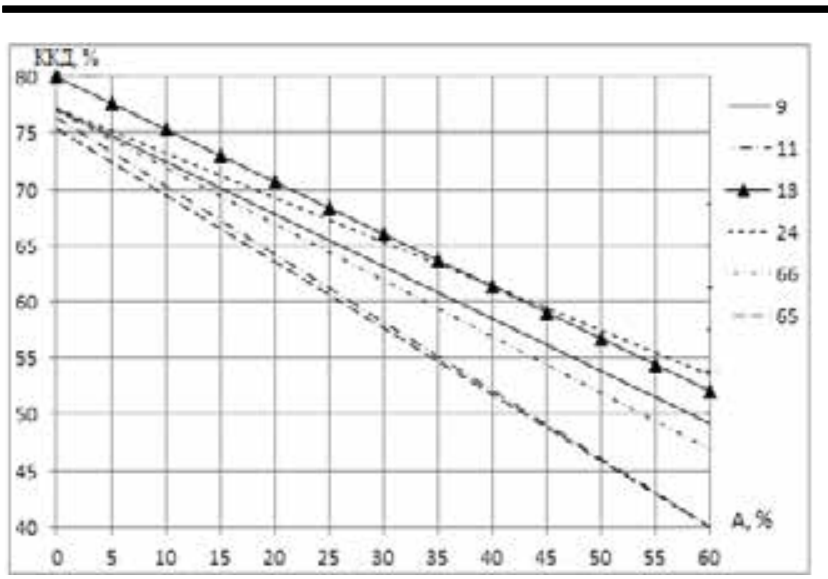

Рис. 2. Функції чутливості хімічного ККД вуглефікації до зміни вмісту зольності вихідного вугілля

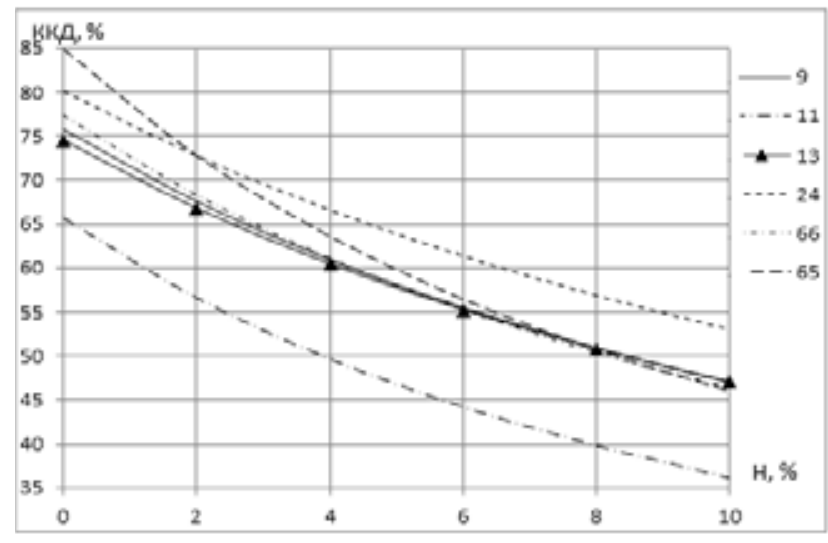

Рис. 3. Функції чутливості хімічного ККД вуглефікації до зміни вмісту водню вихідного вугілля

Таблиця 4

Наведені чутливості хімічного ККД ( $\eta$ до вмісту компонентів вихідного вугілля (розрахунковий варіант)

\begin{tabular}{|c|c|c|c|c|c|c|c|c|}
\hline \multirow{2}{*}{ 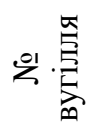 } & \multirow{2}{*}{ 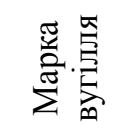 } & \multirow{2}{*}{$\begin{array}{c}\text { Хім. } \\
\text { ККД, }, \text {, } \\
\%\end{array}$} & \multicolumn{6}{|c|}{ Наведені чутливості ๆ до вмісту компонентів вугілля } \\
\hline & & & $\mathrm{d} \eta / \mathrm{dW} \times \mathrm{W} / \mathrm{C}$ & $\mathrm{d} \eta / \mathrm{dA} \times \mathrm{A} / \mathrm{C}$ & $\mathrm{d} \eta / \mathrm{dS} \times \mathrm{S} / \mathrm{C}$ & $\mathrm{d} \eta / \mathrm{dC}$ & $\mathrm{d} \eta / \mathrm{dH} \times \mathrm{H} / \mathrm{C}$ & Сумарна \\
\hline 1 & Ж, P & 63,11 & 0,0007 & 13,9834 & 1,0013 & 23,6022 & $-10,9207$ & $-0,0432$ \\
\hline 2 & Ж, OC & 53,96 & $-0,0062$ & $-22,3895$ & $-1,1998$ & 30,3025 & 9,3471 & $-0,0642$ \\
\hline 3 & $\Pi, \mathrm{P}$ & 65,11 & $-0,0004$ & $-14,8547$ & $-0,9002$ & 24,0341 & 7,8748 & 0,0073 \\
\hline 4 & $\Pi, \mathrm{A}$ & 67,43 & $-0,0001$ & $-9,7231$ & $-0,8586$ & 22,0247 & 11,3937 & 0,0008 \\
\hline 5 & $\Gamma, \mathrm{P}$ & 63,43 & $-0,0012$ & $-13,5092$ & $-1,2169$ & 25,4956 & 16,9492 & $-0,0217$ \\
\hline 6 & 15 & 64,82 & $-0,0021$ & $-10,5427$ & $-1,8704$ & 23,2848 & 16,9492 & $-0,1427$ \\
\hline
\end{tabular}

Запис наведеної чутливості за (15) дає можливість отримати оцінки коефіцієнтів чутливостей за всіма $j$ компонентами складу вихідного вугілля, віднесеними до $1 \%$ маси його вуглецю. Це необхідно для порівняння між собою коефіцієнтів функцій чутливості до компонентів складу різного вугілля в процесі його вибору. Вибір вуглецю тут пов'язаний 3 тим, що в моделі Дешаліта він $є$ єдиним джерелом для горючої частини генераторного газу. На практиці це припущення виконується в зв'язку з порівняно низьким вмістом інших горючих елементів у вихідному вугіллі [3, с. 136].

Як випливає 3 даних таблиці 4, а також 3 рис. 2 і рис. 3, функції чутливості ККД газифікації до зміни вмісту компонентів вихідного палива практично лінійні (окрім вуглецю) на всіх діапазонах їх зміни під час моделювання процесу газифікації. Тому розрахунок цих функцій для всього діапазону моделювання можна замінити розрахунком функцій за проєктним складом вихідного вугілля.

Аналізуючи дані про зв'язок функцій чутливості ККД газифікації зі зміною складу вихідного вугілля, можна зробити висновок про те, що різні знаки цих функцій по-різному впливають на зміну величини самого ККД. Вплив визначається співвідношенням вмісту вуглецю та інших компонентів у робочій масі вихідного вугілля.

Найкращою 3 точки зору отримання штучного газового палива $є$ мінімальна (за абсолютною величиною) сума наведених функцій чутливості, позаяк при цьому забезпечується максимальна стабільність процесу газифікації і відповідно складу генераторного газу.

За даними розрахунків, наведених у таблиці 4, можна зробити попередній вибір вугілля для заданої технології газифікації. Так, мінімальну величину $\mathrm{S}(\mathrm{dy} / \mathrm{dx} \times \mathrm{x} / \mathrm{C})=0.00695\left(\eta_{\text {хім }},=65.11 \%\right)$ має вугілля марки П, Р Донецького басейну. Максимальну величину $\mathrm{S}(\mathrm{dy} / \mathrm{dx} \times \mathrm{x} / \mathrm{C})=-0.14471$ $\left(\eta_{\text {хім }},=64.82 \%\right)$ має вугілля марки 1 Б, Р Александрійське Дніпровського басейну.

Висновки. На основі аналізу перспектив використання сучасних технологій газифікації вугілля для енергетичної галузі України розглянуто важливе для практичної теплоенергетики 
питання оптимального вибору вугілля. Це актуальне ще й тому, що в країні $є$ великі розвідані запаси вугілля, найбільш прийнятного саме для газифікації. Але натепер відсутні формалізовані та практично апробовані методи вибору складу вугілля для наперед заданої технології газифікації.

Для вирішення цього питання запропоновано i розглянуто метод вибору вугілля, заснований на математичній моделі його газифікації. Для цього використано метод газифікації вугілля в стаціонарному шарі під тиском на парокисневому дутті (метод «Лургі»).
Математичну модель процесу основано на методі алгебри Дешаліта, який дає можливість оцінювати склад газового палива та його теплові характеристики. За результатами цього розрахунку визначається хімічний ККД газифікації, який пов'язує між собою склад вихідного вугілля, параметри процесу та характеристики отриманого генераторного газу. Величина цього ККД і його чутливість до зміни складу вихідного вугілля визначають, у кінцевому підсумку, оптимальність зробленого вибору.

За матеріалами моделювання процесу отримано низку рекомендацій для практичного застосування методу.

\section{Список літератури:}

1. Корчевой Ю.П. Экологически чистые угольные энерготехнологии / Ю.П. Корчевой, А.Ю. Майстренко, А.И. Топал. Киев : Наукова думка, 2004. 183 с.

2. Воробьев И.Е. Электроэнергия из органических топлив (обзор, прогнозы, экономика) : пособие для теплоэнергетиков / И.Е. Воробьев, А.Л. Фоменко. Киев : Энергетика и электрификация, 2002. 280 с.

3. Белосельский Б.С. Технология топлива и энергетических масел : учебник для вузов. Москва : Издательство МЭИ, 2003. 340 с.

4. Подгородецкий Г.С. Современные тенденции развития технологии производства генераторных газов из различных видов твердого топлива / Г.С. Подгородецкий, Ю.С. Юсфин, А.Ю. Сажин, В.Б. Горбунов, Л.А. Полулях. Известия высших учебных заведений. Черная металлургия. 2015 Том 58. № 6. C. $393-401$.

5. Хоффман Е. Энерготехнологическое использование угля / пер. с англ. Москва : Энергоатомиздат, 1983. $328 \mathrm{c}$.

6. Топал А. Украина: газификация угля будет востребована. URL: ttps://ukrchem.dp.ua/2014/07/31/ ukraina-gazifikaciya-uglya-budet- vostrebovana.htm.

7. Майстренко О.Ю, Использование супер сверхкритических параметров водяного пара - перспектива развития угольных электростанций Украины / О.Ю. Майстренко, О.Ф. Буляндра, С.М. Василенко. Экотехнологии и ресурсосбережение. 2007. № 5. С. 11-15.

8. ГОСТ 25543-88 Вугілля буре, кам’яне та антрацити. Класифікація за генетичними і технологічними параметрами (Дата скасування дії 01.01.2019).

9. Газификация каменного угля без вредного воздействия на окружающую среду. URL: https://studylib.ru/doc/ 301689.

10. Потапова А. Нет газа без угля. URL: http://ukrrudprom.ua/analytics/Net gaza bez uglya. html?print.

11. Химик Г. Альтернатива Газпрому ... не уголь на ТЭЦ, а газ из угля.... URL: https://cont.ws.

12. Волков И. Газификация бурого угля. URL: https://ukrcoal.at.ua/index/serchcoal/0-59.

13. Загрутдинов Р.Ш., Нагорнов А.Н., Сеначин П.К. Наладочные испытания газогенераторов Лурги и перспективы газогенераторных технологий. Ползуновский вестник. 2007. № 3. С. 40-47.

14. Дешалит Г.И. Расчет процессов газификации топлива : учебное пособие для химико-технологических, металлургических и энергетических специальностей вузов УССР. Харьков : изд-во Харьковского университета, 1959. $170 \mathrm{c}$.

15. Химические вещества из угля. / Пер. с немецкого; под. ред. И.В. Калечица. Москва : Химия, $1980.616 \mathrm{c}$.

16. Абрютин А.А Тепловой расчет котлов (Нормативный метод). Издание 3-е, переработанное и дополненное / А.А. Абрютин, Э.С. Карасина. Санкт-Петербург : Издательство «ВТИ» и НПО «ЦКТИ», 1998. $262 \mathrm{c}$.

17. Авгушевич И.В. Стандартные методы испытания углей. Классификации углей / И.В. Авгушевич, Е.И. Сидорук, Т.М. Броновец. Москва : «Реклама мастер», 2018. 576 с. 


\section{Huley O.B. SELECTION OF OPTIMAL COAL OF UKRAINIAN PRODUCTION FOR PAROKISENE GASIFICATION IN A STATIONARY LAYER}

The aim of the work is to study the possibility of choosing the optimal brand of Ukrainian coal for efficient intra-cycle gasification in the binary thermodynamic cycle at thermal power plants.

Based on the results of the literature review on the topic of the study, it is shown that in studies of coal gasification technologies for gaseous energy fuel, the influence of the composition of the source coal, as a rule, was not the subject of special consideration. Therefore, it is concluded that today there is no universal, systembased method of pre-selection of thermal coal for a predetermined gasification technology.

The subject of the study is the influence of the composition of the source coal on the composition of the generator gas and its main thermal characteristics, which gives grounds for further selection of the optimal composition of coal.

As a criterion for optimal selection, it is proposed to use the value of the chemical efficiency (efficiency) of the gasification process, as well as the total sensitivity of this efficiency to changes in the content of components of the coal composition. depending on the heterogeneity of this composition.

The author used the method of estimating the composition of the generator gas, the alchebraic Deschallite method, as a research tool. The method allows to calculate quantitative estimates of the composition of gasification products depending on the characteristics of the composition of the source coal, the composition of the blast, temperature and pressure in the gas generator. Assumptions in the Deschalit method, as experience has shown, do not lead to significant errors in the estimates.

On the example of common brands of thermal coal by mathematical modeling of the gasification process ("Lurga" technology) the characteristics of gaseous fuel are obtained, on the basis of which it is possible to choose the optimal brand of source coal.

Key words: coal, gas generator, blast, layer, chemical efficiency, specific heat of combustion, temperature, pressure, gas yield, composition, ash content, humidity. 